\title{
Presence and Antibiogram of Inhabiting Marine Bacterial Population at the Upper Sub-surface Water of the South East Coast of Bangladesh, Northern Bay of Bengal
}

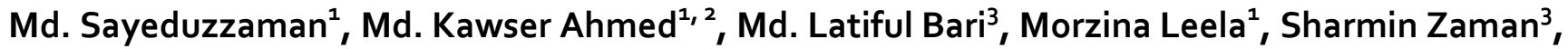 \\ Seema Rani ${ }^{2}$ and Makidul Islam Khan ${ }^{2}$

\begin{abstract}
${ }^{1}$ Department of Oceanography, Faculty of Earth and Environmental Sciences, University of Dhaka, Dhaka 1000, Bangladesh ${ }^{2}$ International Centre for Ocean Governance, Faculty of Earth and Environmental Sciences, University of Dhaka, Dhaka 1000, Bangladesh ${ }^{3}$ Center for Advanced Research of Sciences (CARS), University of Dhaka, Dhaka-1000, Bangladesh
\end{abstract}

Manuscript received: 28 December 2020; accepted for publication: 20 April 2021

\begin{abstract}
The present study was conducted to assess the presence of bacterial populations at the upper sub-surface water from the offshore areas near the South East Coast of Bangladesh, the northern Bay of Bengal and to evaluate their antibiotic resistance pattern. Water samples were collected from 5 stations near the South East Coast of Bangladesh, the northern Bay of Bengal. About 38 marine isolates were primarily identified using conventional cultural methods (Mannitol Salt Agar, Chromocult Coliform Agar and Cetrimide Agar). Among them, two gram negative viz. Pantoea spp. and Pseudomonas aeruginosa and one gram positive viz. Micrococcus spp. were identified and confirmed by biochemical and analytical profiling index techniques. The antibiogram results showed that Pantoea spp. and Micrococcus spp. were sensitive to ciprofloxacin, tetracyclin, erythromycin and chloramphenicol, whereas $P$. aeruginosa was sensitive to ciprofloxacin, azithromycin and streptomycin. However, Pantoea spp. and Micrococcus spp. were resistant to at least 3 antibiotics (oxacillin, cefixime and polymyxin B). But $P$. aeruginosa was resistant to a number of antibiotics such as oxacillin, cefixime, ampicillin, novobiocin, cephalexin, tetracycline, amoxicillin and kanamycin. Increasing drug resistance potential of microbial organisms gives us signal to go for immediate necessary action on the maintenance of water quality of estuarine and coastal areas.
\end{abstract}

Keywords: Marine microorganisms, Antibiogram, Drug resistance, Antibiotics, Bay of Bengal

\section{INTRODUCTION}

Ocean is the great sink of biodiversity including microscopic organisms to giant whale. Marine microbes show great potential for various biotechnological applications in the area of health, environment and agriculture (Azam and Worden, 2004). The number of potential antimicrobial compounds isolated from marine organisms have almost soared and this number now exceeds 10,000 with hundreds of new compounds are still being discovered every year (Proksch et al., 2002). More and more research have been conducted on marine organisms as sustainable sources because of low content of known active compounds in marine animals and plants as well as limitation of bioresource supply.

Ocean is a promising untapped source of novel

Corresponding author: Makidul Islam Khan

Email: makidul07@gmail.com

DOI: https://doi.org/10.3329/dujees.v9i2.55088 bioactive compounds. Because of having potential antibacterial and antifungal properties of marine organisms against bacterial pathogens, they have been profoundly used in the pharmaceutical industries. Jones (1959) collected sea water samples from both oceanic and neritic areas of the Pacific Ocean and used five different cultural and two direct microscopic methods to estimate the abundance of microorganisms. Jannasch and Padmavathy et al. (2015) isolated 51 bacterial strains from five different coastal locations in Gulf of Mannar region, Tamilnadu, India and ten bacterial isolates showed antagonistic activity varied from 14 to $20 \mathrm{~mm}$ against the entire gram positive, gram negative and fungal test pathogens. Overall, globally numerous studies have been conducted to assess the distributions and abundance of microorganisms in marine waters and sediments and analyzed for their potential antimicrobial compounds (Mudryk and Skórczewski, 1998; Do Thi et al., 2012; Valli et al., 2012; Hassan et al., 2015).

The Bay of Bengal, the largest bay of the world, occupies an area of 2.2 million $\mathrm{km}^{2}$ and reaches a 
maximum depth of 5,258 meters. The Bay of Bengal, a northern extended arm of the Indian Ocean, is located between $5^{\circ} \mathrm{N}$ and $22^{\circ} \mathrm{N}$ latitudes and $80^{\circ} \mathrm{E}$ and $100^{\circ} \mathrm{E}$ longitudes. The Bay of Bengal is full of biological diversity that includes coral reefs, fish and shellfish spawning and nursery areas, feeding grounds and coastal mangroves. However, most part of the Bay of Bengal is untapped and there is great prospect to explore the antimicrobial activities of marine organisms in the Bay. Some studies were conducted in different parts of the Bay of Bengal, for example, Sarma et al. (2000), Ramesh et al. (2006), Ramesh and Mathivanan (2009), Sekhar et al. (2012), Verma et al. (2016), etc. to assess antimicrobial activities of marine organisms, but those studies are scatted. Pathak et al. (2012) isolated 6 Pseudomonas and 12 Actinomycetes from rhizoidal soil of coastal vegetation of Rameshwaram, Pichavaram and Thiruvanmayyur regions of the Bay of Bengal and conducted in vitro antimicrobial test using agars well and disc diffusion methods to test their resistance capacity towards antibiotics. Sekhar et al. (2012) collected 28 marine sediment samples from different locations of Visakhapatnam coast of the Bay of Bengal, India and reported that marine microorganisms could be used as vital sources for bioactive molecules as they showed useful antimicrobial activity. However, in northern part of the Bay of Bengal, there is scarce study on marine microorganism's abundance, distributions and their bioactive compounds. So, the present study was conducted to assess the presence of microbes at the upper sub-surface water from the offshore areas near the South East Coast of Bangladesh, the northern Bay of Bengal and to evaluate their antibiotic resistance pattern.

\section{MATERIALS AND METHODS}

\section{Site selection and sample collection}

Water samples were collected from a one-month winter cruise of the Department of Oceanography, University of Dhaka using Agro Food-4 Fishing Trawler of Sea Resource Company Ltd. from five (5) stations of the south of south patches off the South East Coast of Bangladesh. The sample water collected from a depth of 5 meter (Table 1 and Figure 1) by Niskin bottles in January, 2016. Special care was taken during sampling and collecting water samples. The samples were preserved in individual clear plastic bottles in order to prevent cross contamination of bacteria between water samples.

Table 1. Sampling Stations of the South East Coast of Bangladesh, Northern Bay of Bengal

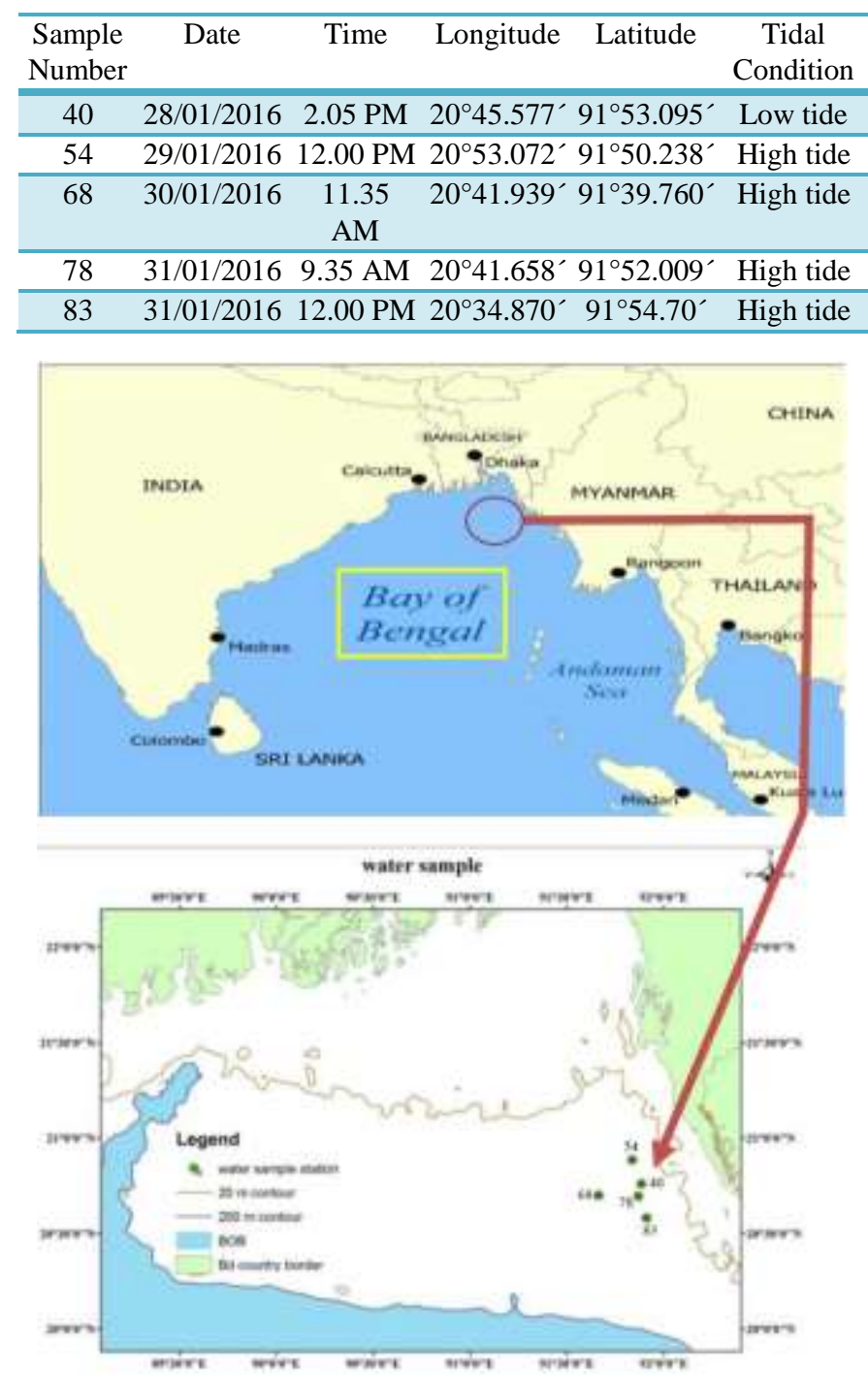

Figure 1. Sampling Stations of the South East Coast of Bangladesh, the Northern Bay of Bengal

\section{Laboratory investigation}

Sample analyses were carried out in the Food Microbiology and Research Laboratory of the Center for Advanced Research in Sciences (CARS), University of Dhaka.

\section{Bacteriological methods}

\section{Inoculation in Marine Agar}

At the beginning, Marine Agar (MA) media (DIFCO Marine Agar 2216) was prepared for inoculation of water sample in anaerobic condition. 
Then samples name, date and sample number were labelled with the MA plates carefully. MA plate was stored at $37^{\circ} \mathrm{C}$ incubator for 24 hours and checked the contamination level. The fresh plates were inoculated with $100 \mu$ of the seawater sample by pipetting $100 \mu 1$ onto the plate in biosafety cabinet. After spreading, the plates were incubated at $37^{\circ} \mathrm{C}$ temperature and incubated plates were examined for colony formation after $24-48$ and 72 hours.

\section{Isolation of bacterium in selective growth media}

Streaked each of the colonies for further analysis on fresh MA plates to isolate single colonies. Colonies were streaked onto CHR (Chromo Cult Coliform Agar), MSA (Mannitol Salt Agar) and CET (Cetrimide Agar) plates for pure culture as well as for confirmation. For growth of isolated colony, the organisms were incubated at $37^{\circ} \mathrm{C}$ for 24 to 72 hours. After then, isolates were transferred to another $1.5 \mathrm{ml}$ eppendorfs containing $20 \%$ glycerol broth and stored at $-20^{\circ} \mathrm{C}$ temperature. Rest of the plates were sealed with parafilm and store at $4^{\circ} \mathrm{C}$ temperature.

\section{Biochemical test}

Presumptive identification and confirmation of specific bacterial population were done by conventional biochemical tests. These biochemical tests included Methyl Red/Voges-Proskauer (MR/VP), Indole, Simmon's Citrate, Catalase, Oxidase and Carbohydrate Fermentation (Sucrose and Dextrose) tests. Tests were performed for the identification of the isolates following the methods of Cappuccino and Sherman (1996).

\section{Identification of isolates using analytical profile index (API) system}

Three types of API viz. API 20 E, API 20 NE and API STAPH test were performed to identify the isolates following the methods of Holmes et al. (1978).

\section{KIRBY-BAUER test for antibiotic sensitivity}

Kirby-Bauer test (Bauer et al., 1966) was employed to evaluate antibiotic sensitivity for different bacteria.

\section{Statistical analysis}

Microsoft Excel (version-13) were employed for data analysis and to prepare the tables and graphs.

\section{RESULTS AND DISCUSSION}

\section{Cultural properties of the samples}

Colonies of bacterial populations showed different colors in different selective agar media (Table 2 and Figure 2). The presence of bacterial colonies in water samples are agar specific and depending on their morphological characteristics, biochemical and API tests are performed for their confirmation. In this study, around 38 marine isolates were primarily identified using conventional cultural methods (MSA, CHR and CET). Out of 38 marine isolates, two gram negative bacteria viz. Pantoea spp. and Pseudomonas aeruginosa and one gram positive bacteria viz. Micrococcus spp. were identified and characterized (Table 2).

Table 2. Colony Characteristics of Bacterial Population in Different Selective Agar Media

\begin{tabular}{lllllll}
\hline Organisms & Media & $\begin{array}{l}\text { Colony } \\
\text { size }\end{array}$ & $\begin{array}{l}\text { Colony } \\
\text { shape }\end{array}$ & $\begin{array}{l}\text { Colony } \\
\text { color }\end{array}$ & Elevation & Texture \\
\hline $\begin{array}{l}\text { Micrococcus } \\
\text { spp. }\end{array}$ & MSA & Small & Round & $\begin{array}{l}\text { Light } \\
\text { pink }\end{array}$ & Raised & Smooth \\
\hline $\begin{array}{l}\text { Pantoea } \text { spp. } \\
\text { CHR }\end{array}$ & Medium & Convex & $\begin{array}{l}\text { Off } \\
\text { white }\end{array}$ & Flat & Smooth \\
\hline $\begin{array}{l}\text { Pseudomonas } \\
\text { aeruginosa }\end{array}$ & CET & Medium & Rod & $\begin{array}{l}\text { Bright } \\
\text { green }\end{array}$ & Flat & $\begin{array}{l}\text { Transluce } \\
\text { nt smooth }\end{array}$ \\
\hline
\end{tabular}
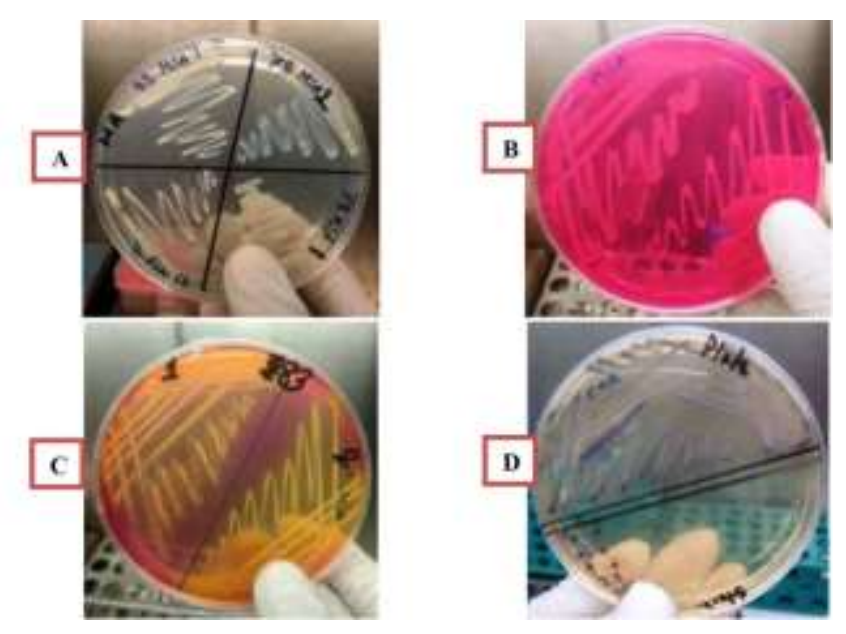

Figure 2. Bacterial Colonies on - A. MA (Marine Agar), B and C. MSA (Mannitol Salt Agar), and D. CHR (Chromocult Coliform Agar)

\section{Biochemical tests}

Bacterial colonies from different agar media were used for biochemical tests. Micrococcus spp., Pantoea spp. and $P$. aeruginosa showed positive results only for VP, Catalase and Oxidase; MR, Catalase and Sucrose; and Catalase, Oxidase and Citrate, respectively (Table 3 ). None of the bacteria showed 
any result for Indole, Lactose and Dextrose tests. All

confirmation.

these samples were later used for API test for bacterial

Table 3. Biochemical Properties of Marine Bacteria Isolated from Upper Sub-surface Water from the Offshore Areas Near the South East Coast of Bangladesh, the Northern Bay of Bengal

\begin{tabular}{|c|c|c|c|c|c|c|c|c|c|}
\hline \multirow{2}{*}{ Organisms } & \multicolumn{9}{|c|}{ Name of biochemical tests } \\
\hline & MR & $\mathrm{VP}$ & Indole & Catalase & Oxidase & Citrate & Lactose & Sucrose & Dextrose \\
\hline $\begin{array}{l}\text { Micrococcus } \\
\text { spp. }\end{array}$ & - & + & - & + & + & - & - & - & - \\
\hline Pantoea spp. & + & - & - & + & - & - & - & + & - \\
\hline $\begin{array}{l}\text { Pseudomonas } \\
\text { aeruginosa }\end{array}$ & - & - & - & + & + & + & - & - & - \\
\hline
\end{tabular}

\section{API tests to confirm the identity of the isolates}

After cultural identification and biochemical test, API 20 E (bioMerieux, France) tests were performed to confirm the identity of Pantoea spp. (Enterobacteriaceae group) from water off the South East Coast of Bangladesh, the northern Bay of Bengal according to the reading table and identification software (Table 4).
In contrast, API 20 NE (bioMerieux, France) tests were performed to confirm the identity of $P$. aeruginosa from water off the South East Coast of Bangladesh, the northern Bay of Bengal according to the reading table and identification software (Table 5). API 20 E (bioMerieux, France) tests did not give any result for $P$. aeruginosa since it showed positive results for Oxidase test. API $20 \mathrm{E}$ is used for gram negative bacteria that are oxidase negative.

Table 4. Interpretation Table of API 20 ETtest (adapted from bioMerieux.com)

\begin{tabular}{|c|c|c|c|c|c|}
\hline \multirow[t]{2}{*}{ Tests } & \multirow[t]{2}{*}{ Active ingredients } & \multirow{2}{*}{$\begin{array}{c}\text { Qty } \\
\text { (mg/cup) }\end{array}$} & \multirow[t]{2}{*}{ Reactions/Enzymes } & \multicolumn{2}{|c|}{ Results } \\
\hline & & & & Negative & Positive \\
\hline ONPG & $\begin{array}{l}\text { 2-nitrophenyl } \beta \mathrm{D}- \\
\text { galactopyranoside }\end{array}$ & 0.223 & $\beta$ galactosidase & Colorless & Yellow \\
\hline $\mathrm{ADH}$ & L-arginine & 1.9 & Arginine Dihydrolase & Yellow & Red/Orange \\
\hline$\underline{\mathrm{LDC}}$ & L-Lysine & 1.9 & Lysine Decarboxylase & Yellow & Red/Orange \\
\hline$\underline{\mathrm{ODC}}$ & L-Ornithine & 1.9 & Ornithine Decarboxylase & Yellow & Red/Orange \\
\hline CIT & Tri sodium citrate & 0.756 & Citrate Utilization & Pale green/ yellow & Blue-green/ blue \\
\hline$\underline{\mathrm{H}_{2}} \underline{\mathrm{S}}$ & Sodium Thiosulphate & 0.075 & $\mathrm{H}_{2} \mathrm{~S}$ production & Colorless/greyish & $\begin{array}{l}\text { Black deposit/thin } \\
\text { line }\end{array}$ \\
\hline$\underline{\mathrm{URE}}$ & Urea & 0.76 & Urease & Yellow & Red/Orange \\
\hline \multirow[t]{2}{*}{ TDA } & L-tryptophan & 0.38 & Tryptophan deaminase & \multicolumn{2}{|c|}{ TDA /Immediate } \\
\hline & & & & Yellow & Reddish Brown \\
\hline \multirow[t]{2}{*}{ IND } & L-tryptophan & 0.19 & Indole Production & \multicolumn{2}{|c|}{ James/ Immediate } \\
\hline & & & & $\begin{array}{c}\text { Colorless } \\
\text { Pale green/yellow }\end{array}$ & Pink \\
\hline \multirow[t]{2}{*}{ VP } & Sodium Pyruvate & 0.19 & Acetoin Production & \multicolumn{2}{|c|}{$\mathrm{VP}_{1}+\mathrm{VP}_{2} / 10 \mathrm{~min}$} \\
\hline & & & (Voges Proskauer) & Colorless & Pink/red \\
\hline Gel & $\begin{array}{l}\text { Gelatin (Bovine } \\
\text { origin) }\end{array}$ & 0.6 & Gelatinase & No difusion & $\begin{array}{c}\text { Diffusion of black } \\
\text { pigment }\end{array}$ \\
\hline GLU & D-glucose & 1.9 & Fermentation/Oxidation (GLU) & Blue/Blue-Green & $\begin{array}{c}\text { Yellow/Greyish } \\
\text { yellow }\end{array}$ \\
\hline MAN & D-Mannitol & 1.9 & Fermentation/Oxidation(MAN) & Blue/Blue-Green & Yellow \\
\hline INO & Inositol & 1.9 & Fermentation/Oxidation (INO) & Blue/Blue-Green & Yellow \\
\hline SOR & D-Sorbitol & 1.9 & Fermentation/Oxidation(SOR) & Blue/Blue-Green & Yellow \\
\hline RHA & L-Rhamnose & 1.9 & Fermentation/Oxidation(RHA) & Blue/Blue-Green & Yellow \\
\hline SAC & D-Sucrose & 1.9 & Fermentation/Oxidation(SAC) & Blue/Blue-Green & Yellow \\
\hline MEL & D-Mellibiose & 1.9 & Fermentation/Oxidation(MEL) & Blue/Blue-Green & Yellow \\
\hline AMY & Amygdaline & 0.57 & Fermentation/Oxidation(AMY) & Blue/Blue-Green & Yellow \\
\hline
\end{tabular}




\begin{tabular}{|c|c|c|c|c|c|}
\hline ARA & L-arabinose & 1.9 & Fermentation/Oxidation(ARA) & Blue/Blue-Green & Yellow \\
\hline \multirow[t]{2}{*}{ Tests } & \multirow[t]{2}{*}{ Active Ingredients } & \multirow{2}{*}{$\begin{array}{c}\text { Qty } \\
\text { (mg/cup) }\end{array}$} & \multirow[t]{2}{*}{ Reactions/Enzymes } & \multicolumn{2}{|c|}{ Results } \\
\hline & & & & Negative & Positive \\
\hline \multirow[t]{3}{*}{ NO3 } & \multirow[t]{3}{*}{ potassium nitrate } & \multirow[t]{3}{*}{01.36} & \multirow[t]{2}{*}{ reduction of nitrates to nitrites } & \multicolumn{2}{|c|}{ NIT $1+$ NIT $2 / 5 \mathrm{~min}$} \\
\hline & & & & Colorless & Pink-Red \\
\hline & & & reduction of nitrates to nitrogen & Pink & Colorless \\
\hline \multirow[t]{2}{*}{ TRP } & \multirow[t]{2}{*}{ L-tryptophane } & \multirow[t]{2}{*}{0.2} & \multirow[t]{2}{*}{ indole production (TRyptoPhane) } & \multicolumn{2}{|c|}{ JAMES / immediate } \\
\hline & & & & $\begin{array}{c}\text { colorless } \\
\text { pale green / } \\
\text { yellow }\end{array}$ & Pink \\
\hline ESC & Esculin ferric citrate & $\begin{array}{c}0.56 \\
0.072\end{array}$ & hydrolysis ( $\beta$-glucosidase) (ESCulin) & Yellow & $\begin{array}{l}\text { grey / brown } \\
\text { /black }\end{array}$ \\
\hline GEL & $\begin{array}{c}\text { gelatin } \\
\text { (bovine origin) }\end{array}$ & 0.6 & hydrolysis (protease) (GELatin) & $\begin{array}{l}\text { no pigment } \\
\text { diffusion }\end{array}$ & $\begin{array}{c}\text { diffusion of } \\
\text { black pigment }\end{array}$ \\
\hline PNPG & $\begin{array}{c}\text { 4-nitrophenyl- } \\
\beta \text { Dgalactopyranoside }\end{array}$ & 0.22 & $\begin{array}{c}\beta \text {-galactosidase (Para-NitroPhenyl- } \\
\text { BDGalactopyranosidase) }\end{array}$ & Colorless & Yellow \\
\hline GLU & D-glucose & 1.56 & assimilation (GLUcose) & transparent & opaque \\
\hline ARA & L-arabinose & 1.4 & assimilation (ARAbinose) & transparent & opaque \\
\hline MNE & D-mannose & 1.4 & assimilation (ManNosE) & transparent & opaque \\
\hline MLT & malic acid & 1.56 & assimilation (MaLaTe) & transparent & opaque \\
\hline CIT & trisodium citrate & 2.28 & assimilation (trisodium CITrate) & transparent & opaque \\
\hline PAC & phenylacetic acid & 0.8 & assimilation (PhenylACetic acid) & transparent & opaque \\
\hline
\end{tabular}

Table 6. Interpretation Table of API STAPH Test (adapted from bioMerieux.com)

\begin{tabular}{|c|c|c|c|c|c|}
\hline \multirow[t]{2}{*}{ Tests } & \multirow[t]{2}{*}{ Active Ingredients } & \multirow{2}{*}{$\begin{array}{c}\text { Qty } \\
\text { (mg/cup) }\end{array}$} & \multirow[t]{2}{*}{ Reactions/Enzymes } & \multicolumn{2}{|c|}{ Results } \\
\hline & & & & Negative & Positive \\
\hline 0 & No Substrate & & Negative control & red & - \\
\hline GLU & D-glucose & 1.56 & (Positive control) (D-glucose) & red & yellow \\
\hline FRU & D-Fructose & 1.4 & $\begin{array}{l}\text { acidification } \\
\text { (D-Fructose) }\end{array}$ & & \\
\hline MNE & D-Mannose & 1.4 & $\begin{array}{l}\text { acidification } \\
\text { (D-Mannose) }\end{array}$ & & \\
\hline MAL & D-Maltose & 1.4 & acidification (Maltose) & & \\
\hline LAC & D-Lactose & 1.4 & acidification (Lactose) & & \\
\hline TRE & D-Trehalose & 1.32 & $\begin{array}{l}\text { acidification } \\
\text { (D-Trehalose) }\end{array}$ & & \\
\hline MAN & D-Mannitol & 1.36 & $\begin{array}{l}\text { acidification } \\
\text { (D-Mannitol) }\end{array}$ & & \\
\hline
\end{tabular}




\begin{tabular}{|c|c|c|c|c|c|}
\hline MEL & D-Melibiose & 1.32 & $\begin{array}{l}\text { acidification } \\
\text { (D-Melibiose) }\end{array}$ & & \\
\hline \multirow[t]{2}{*}{ NIT } & \multirow[t]{2}{*}{ Potassium Nitrate } & \multirow[t]{2}{*}{0.08} & \multirow[t]{2}{*}{ Reduction of Nitrates to nitrites } & \multicolumn{2}{|c|}{ NIT 1+NIT $2 / 10 \mathrm{~min}$} \\
\hline & & & & colorless-light pink & red \\
\hline \multirow[t]{2}{*}{ PAL } & $\beta$-naphthyl phosphate & 0.0244 & Alkaline phosphatase & \multicolumn{2}{|c|}{$\mathrm{ZYM} \mathrm{A}=\mathrm{ZYM} \mathrm{B} / 10 \mathrm{~min}$} \\
\hline & & & & yellow & violet \\
\hline \multirow[t]{2}{*}{ VP } & Sodium pyruvate & 1.904 & Acetyl-methyl-carbinol & \multicolumn{2}{|c|}{$\mathrm{VP} 1=\mathrm{VP} 2 / 10 \mathrm{~min}$} \\
\hline & & & production (voges proskauer) & colorless-light pink & violet pink \\
\hline RAF & D-raffinose & 1.56 & acidification (Raffinose) & \multirow[t]{5}{*}{ red } & \multirow[t]{5}{*}{ yellow } \\
\hline XYL & D-xylose & 1.4 & acidification (Xylose) & & \\
\hline SAC & D-sacchrose (Sucrose) & 1.32 & acidification (Saccharose) & & \\
\hline MDG & $\begin{array}{c}\text { methyl- } \alpha \mathrm{D}- \\
\text { glucopyranoside }\end{array}$ & 1.28 & $\begin{array}{l}\text { acidification (Methyl- } \alpha \text { D- } \\
\text { glucopyranoside) }\end{array}$ & & \\
\hline NAG & $\mathrm{N}$-acetyl-glucosamine & 1.28 & $\begin{array}{l}\text { acidification ( } \mathrm{N} \text {-acetyl- } \\
\text { glucosamine) }\end{array}$ & & \\
\hline $\mathrm{ADH}$ & L-arginine & 1.904 & Arginine Dihudrolase & yellow & orange-red \\
\hline URE & Urea & 0.76 & UREase & yellow & red-violet \\
\hline
\end{tabular}

In case of Micrococcus spp., API STAPH (bioMerieux, France) tests were performed to confirm the identification of Micrococcus spp. from water off the South East Coast of Bangladesh, the northern Bay of Bengal (Table 6).

\section{Antibiogram of identified bacterial populations}

Biochemically identified bacterial populations were further screened for different antibiotics and some isolates showed positive results. This study showed that Pantoea spp. and Micrococcus spp. were highly sensitive to ciprofloxacin, tetracyclin, erythromycin and chloramphenicol (Figure 6 and 7), whereas $P$. aeruginosa was sensitive to ciprofloxacin, azithromycin and streptomycin (Figure 8).

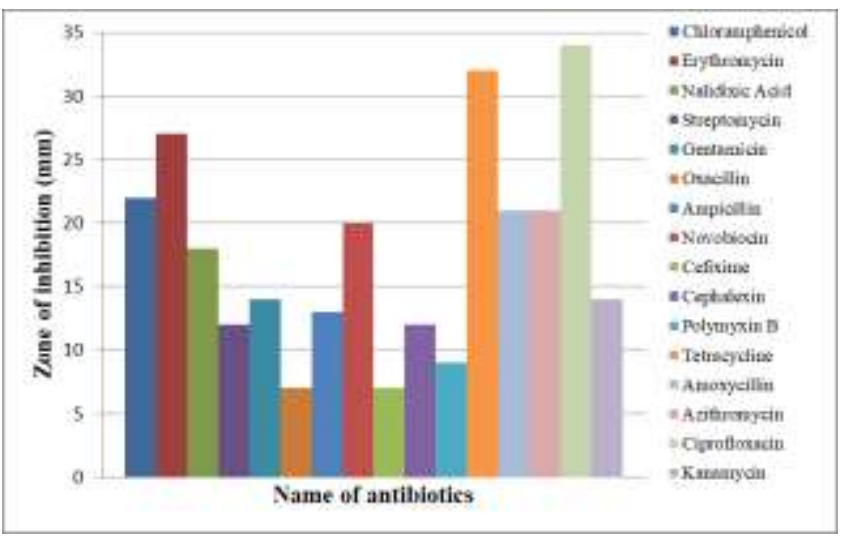

Figure 6. Antibiogram Patterns for Pantoea spp.

However, the antibiogram results showed that Pantoea and Micrococcus spp. were resistant to at least 3 antibiotics (oxacillin, cefixime and polymyxin B) (Figure 6 and 7). But P. aeruginosa was resistant to a number of antibiotics such as oxacillin, cefixime, ampicillin, novobiocin, cephalexin, tetracycline, amoxicillin and kanamycin (Figure 8). Possible resistant pattern might be occurred due to chromosome and plasmid mediated drug resistance of respective bacteria. Some other reasons e.g., drug efflux pump might also be responsible for drug resistance of respective bacteria. The increase of resistance potential micro flora shows the importance of water quality maintenance.

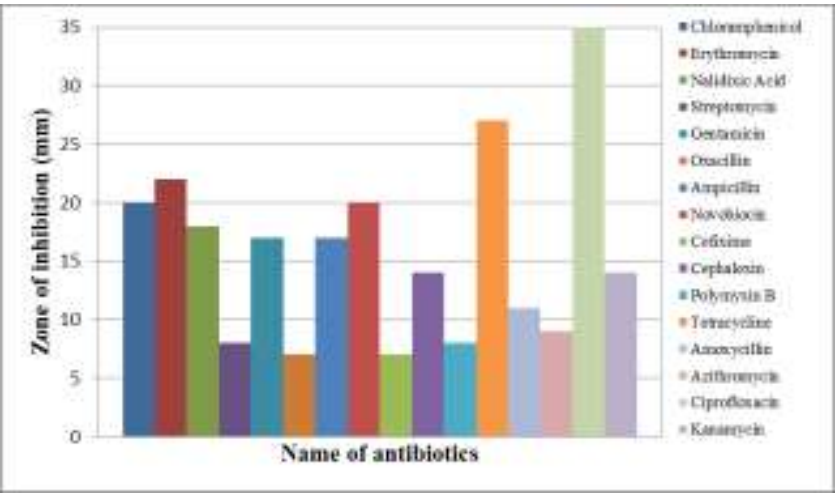

Figure 7. Antibiogram Patterns for Micrococcus spp.

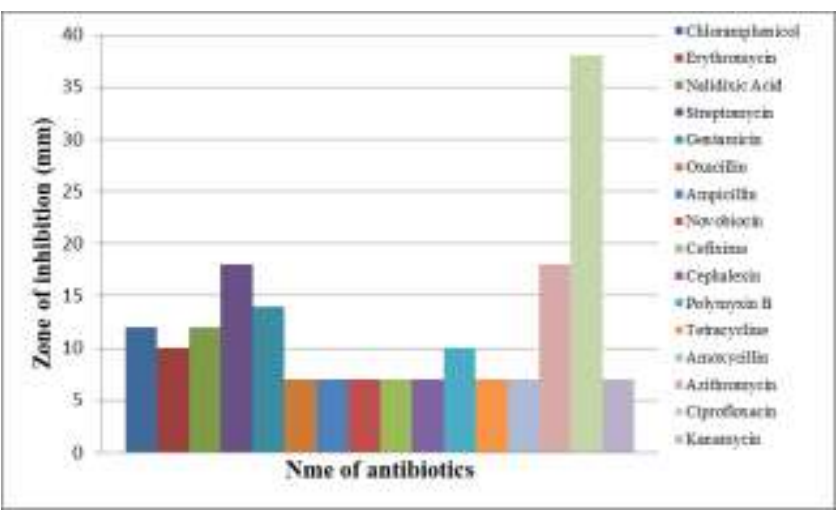


Figure 8. Antibiogram Patterns for Pseudomonas aeruginosa

Marine habitats are important sources for supplying living and non-living resources including social and economic goods and services. Among the three major habitats of the biosphere, the marine realm which covers $70 \%$ of the earth's surface provides the largest inhabitable space for living organisms, particularly microbes. Marine microbes flourish not only in the surface waters of the sea, but also in the lower and abyssal depths from coastal to the offshore regions, and from the general oceanic to the specialized niches like blue waters of coral reefs to black smokers of hot thermal vents at the sea floor (Das et al., 2006). Assessing and exploring microbial diversity is clearly a topic of considerable importance and interest. Besides, analysis of microbial biodiversity helps in isolating and identifying new and potential microorganisms having high specificity for recalcitrant compounds (Ely et al., 2004; Wietz et al., 2010; Stincone and Brandelli, 2020).

This study identified around 38 isolates from the water off the South East Coast of Bangladesh which might provide many bioactive compounds that have biotechnological prospective as antibiotics, biosurfactants, antifungal, or anticancer agents (Demain and Sanchez, 2009; Hibbing et al., 2010). Among 38 isolates, this study found two gram negative bacteria viz. Pantoea spp. and $P$. aeruginosa and one gram positive bacteria named Micrococcus spp. from the sub-surface coastal water of the northern Bay of Bengal. The role of Pantoea spp. is ambiguous because of its epiphytic and endophytic nature (Dutkiewicz et al., 2015). However, it could produce bioactive compounds effective in dealing with cancer and other diseases of humans, defeats the growth of numerous plant pathogens, stimulates plant development, and appears as a potentially effective biofertilizer and bioremediator (Dutkiewicz et al., 2016). P. aeruginosa and Micrococcus spp. can also produce bioactive compounds shown by, for example, de Oliveira et al. (2016), Anayo et al. (2019), Karbalaei-Heidari et al. (2020), etc.

However, marine bacteria are increasingly becoming antibiotic resistant that impose a great risk for environmental safety and human health concern (Korajkic et al., 2020). In this study, it was found that Pantoea spp., Micrococcus spp. and P. aeruginosa were highly sensitive to only a few antibiotics such as ciprofloxacin. In contrast, they are resistant to a number of antibiotics such as oxacillin, cefixime and polymyxin B. $P$. aeruginosa is a key pathogen accountable for infections in patients who suffer from breathing diseases (Saxena et al., 2014). P. aeruginosa can result in hard-to-treat life threatening diseases because of its high resistance to antibiotics and to the ability to form antibiotic tolerant biofilms (Papa et al., 2015). The increasing antibiotic resistant power of marine microbes have threatened human health.

The incidence of high percentages of marine bacteria resistant to antimicrobials indicate that marine environment is contaminated by different sources which make bacteria resistant against antimicrobials. For example, entrance of nonindigenous bacteria in marine ecosystems (de Oliveira et al., 2010), coastal runoff from terrestrial sources, anthropogenic antibiotic runoff which challenges native bacteria to become resistant and antibiotic production in marine environments (Hatosy and Martiny, 2015). Increasing drug resistance potential of microbial organisms gives us signal to take immediate necessary actions and strategies in order to conserve the estuarine and coastal water quality from degradation. This study suggests proper management strategies should be taken to monitor microbial community in marine environment and control antibiotic resistant pathogens.

\section{CONCLUSIONS}

In this study, presence of bacterial populations at the upper sub-surface water from the offshore areas near the South East Coast of Bangladesh, the northern Bay of Bengal was assessed and their antibiogram were tested. Around 38 marine isolates were primarily identified using cultural, biochemical and immune assay techniques. Among them, two gram negative and one gram positive bacteria were identified. The antibiogram results revealed that these three bacteria showed antibiotic resistant to a number of antibiotics such as oxacillin and cefixime. Since bacteria can live and reproduce in a variety of environments including animals, humans, water, soils and foods, their drug resistant power could impose a threat for human health. In addition, microorganisms increasing drug resistance potential reflects an alarming signal for water quality maintenance. Unnecessary and excessive use of antibiotics are responsible for occurrence of the drug resistant pathogenic bacteria in 
the aquatic environment. More studies should be conducted in the Bay of Bengal for proper understanding about the distribution of microbial populations, their life cycle, antibiogram, and to monitor trends in antibiotic susceptibilities.

Acknowledgements: Food Microbiology and Research Laboratory of the Center for Advanced Research in Sciences (CARS), University of Dhaka is gratefully thanked for permission to carry out laboratory experiments. We would like to thank the Sea Resource Company Ltd. for the necessary permission to get on board for 1 month cruise using the Agro Food-4 Fishing Trawler. We also extend our sincere thanks to Scientific Officers Mr. Kazi Belayet Hossain, Rupak Loodh, and Sultan Al Nahian of Bangladesh Oceanographic Research Institute (BORI) and Abdullah-al-Hasan, Assistant Professor of Patuakhali Science and Technology University (PSTU) for water collection.

\section{CONFLICTS OF INTEREST}

The authors have no conflicts of interest to declare.

\section{REFERENCES}

Anayo, O. F., Peter, O. C., Nneji, U. G., Obinna, A., Scholastica, E. C., \& Mistura, L. O. (2019). The Beneficial Roles of Pseudomonas in Medicine, Industries, and Environment: A. Pseudomonas Aeruginosa: An Armory Within, 97.

Azam, F., \& Worden, A. Z. (2004). Microbes, molecules, and marine ecosystems. Science, 303(5664), 16221624.

Bauer, A. W., Kirby, W. M. M., Sherris, J. C., \& Tuck, M. (1996). Antibiotic susceptibility testing by a standardized single disk method. American Journal of Clinical Pathology. 1966, 45: 493-496.

Cappuccino, J. G., \& Sherman, N. (1996). Microbiology: a laboratory manual. $10^{\text {th }}$ edition. The Benjamin Cummings Publishing Company Inc., San Francisco.

Das, S., Lyla, P. S., \& Khan, S. A. (2006). Marine microbial diversity and ecology: importance and future perspectives. Current Science, 90(10), 1325-1335.

de Oliveira, A. G., Spago, F. R., Simionato, A. S., Navarro, M. O., da Silva, C. S., Barazetti, A. R., Cely, M. V., Tischer, C. A., San Martin, J. A., de Jesus Andrade, C. G., \& and Novello, C. R., (2016). Bioactive organocopper compound from Pseudomonas aeruginosa inhibits the growth of Xanthomonas citri subsp. citri. Frontiers in microbiology, 7, 113.

de Oliveira, A. J. F. C., De França, P. T. R., \& Pinto, A. B. (2010). Antimicrobial resistance of heterotrophic marine bacteria isolated from seawater and sands of recreational beaches with different organic pollution levels in southeastern Brazil: evidences of resistance dissemination. Environmental monitoring and assessment, 169(1), 375-384.

Demain, A. L., \& Sanchez, S. (2009). Microbial drug discovery: 80 years of progress. The Journal of antibiotics, 62(1), 5-16.

Do Thi, T., Le Dinh, Q., Dinh, T. Q., \& Van, C. P. (2012). Isolation and identification of marine bacteria from marine mud in Vietnam with antimicrobial activity. Journal of Vietnamese Environment, 3(2), 71-75.

Dutkiewicz, J., Mackiewicz, B., Lemieszek, M. K., Golec, M., \& Milanowski, J. (2016). Pantoea agglomerans: a mysterious bacterium of evil and good. Part IV. Beneficial effects. Annals of Agricultural and Environmental Medicine, 23(2).

Dutkiewicz, J., Mackiewicz, B., Lemieszek, M. K., Golec, M., \& Milanowski, J. (2015). Pantoea agglomerans: a mysterious bacterium of evil and good. Part I. Deleterious effects: dust-borne endotoxins and allergens-focus on cotton dust. Annals of Agricultural and Environmental Medicine, 22(4).

Ely, R., Supriya, T., \& Naik, C. G. (2004). Antimicrobial activity of marine organisms collected off the coast of South East India. Journal of experimental marine biology and ecology, 309(1), 121-127.

Hassan, S. W. M., Abdul-Raouf, U. M., \& Ali, M. A. R. (2015). Antagonistic interactions and phylogenetic diversity of antimicrobial agents producing marine bacteria in Suez Bay. The Egyptian Journal of Aquatic Research, 41(1), 57-67.

Hatosy, S. M., \& Martiny, A. C. (2015). The ocean as a global reservoir of antibiotic resistance genes. Applied and environmental microbiology, 81(21), 7593-7599.

Hellweger, F. L., Van Sebille, E., Calfee, B. C., Chandler, J. W., Zinser, E. R., Swan, B. K., \& Fredrick, N. D. (2016). The role of ocean currents in the temperature selection of plankton: insights from an individualbased model. PloS one, 11(12), e0167010.

Hibbing, M. E., Fuqua, C., Parsek, M. R., \& Peterson, S. B. (2010). Bacterial competition: surviving and thriving in the microbial jungle. Nature reviews microbiology, $8(1), 15-25$.

Holmes, B., Willcox, W. R., \& Lapage, S. P. (1978). Identification of Enterobacteriaceae by the API 20E system. Journal of Clinical Pathology, 31(1), 22-30.

Jannasch, H. W., \& Jones, G. E. (1959). Bacterial populations in sea water as determined by different methods of enumeration. Limnology and Oceanography, 4(2), 128-139. 
Karbalaei-Heidari, H. R., Partovifar, M., \& MemarpoorYazdi, M. (2020). Evaluation of the Bioactive Potential of Secondary Metabolites Produced by a New Marine Micrococcus Species Isolated from the Persian Gulf. Avicenna journal of medical biotechnology, 12(1), 61.

Korajkic, A., McMinn, B. R., Staley, Z. R., Ahmed, W., \& Harwood, V. J. (2020). Antibiotic-Resistant Enterococcus Species in Marine Habitats: A Review. Current Opinion in Environmental Science \& Health.

Logan, N. A., \& Berkeley, R. C. W. (1984). Identification of Bacillus strains using the API system. Microbiology, 130(7), 1871-1882.

Mudryk, Z., \& Skórczewski, P. (1998). Antibiotic resistance in marine neustonic and planktonic bacteria isolated from the Gdańsk Deep. Oceanologia, (40 (2)), 125-136.

Papa, R., Selan, L., Parrilli, E., Tilotta, M., Sannino, F., Feller, G., Tutino, M. L., \& and Artini, M., (2015). Anti-biofilm activities from marine cold adapted bacteria against Staphylococci and Pseudomonas aeruginosa. Frontiers in microbiology, 6, p.1333.

Pathak, M., Verma, T. K., Kalita, D., \& Sankari, D. (2012). Antimicrobial properties of marine bacteria isolated from the Bay of Bengal and their pharmaceutical prospects as antibiotics against multi drug resistant pathogens. International Journal of Pharmacy and Pharmaceutical Sciences, 4(4), 260-263.

Proksch, P., Edrada, R., \& Ebel, R. (2002). Drugs from the seas-current status and microbiological implications. Applied microbiology and biotechnology, 59(2), 125134.

Ramesh, S., \& Mathivanan, N. (2009). Screening of marine actinomycetes isolated from the Bay of Bengal, India for antimicrobial activity and industrial enzymes. World Journal of Microbiology and Biotechnology, 25(12), 2103-2111.
Ramesh, S., Jayaprakashvel, M., \& Mathivanan, N. (2006). Microbial status in seawater and coastal sediments during pre-and post-tsunami periods in the Bay of Bengal, India. Marine Ecology, 27(3), 198-203.

Sarma, K. V. L. N. S., Ramana, M. V., Subrahmanyam, V., Krishna, K. S., Ramprasad, T., \& Desa, M. (2000). Morphological features in the Bay of Bengal. J. Ind. Geophys. Union, 4(2), 185-190.

Saxena, S., Banerjee, G., Garg, R., \& Singh, M. (2014). Comparative study of biofilm formation in Pseudomonas aeruginosa isolates from patients of lower respiratory tract infection. Journal of clinical and diagnostic research: JCDR, 8(5), DC09.

Sekhar, M. D. A. G. C., Krishna, E. R., Kumar, P. S., \& Mohan, C. M. (2012). Isolation and screening of antimicrobial activity of marine sediment bacteria from Bay of Bengal Coast, Visakhapatnam. Journal of Pharmacy Research, 5(3), 1318-1319.

Stincone, P., \& Brandelli, A. (2020). Marine bacteria as source of antimicrobial compounds. Critical reviews in biotechnology, 40(3), 306-319.

Valli, S., Suvathi, S. S., Aysha, O. S., Nirmala, P., Vinoth, K. P., \& Reena, A. (2012). Antimicrobial potential of Actinomycetes species isolated from marine environment. Asian Pacific Journal of Tropical Biomedicine, 2(6), 469-473.

Verma, P., Raghavan, R. V., Jeon, C. O., Lee, H. J., Priya, P. V., Dharani, G., \& Kirubagaran, R. (2016). Complex bacterial communities in the deep-sea sediments of the Bay of Bengal and volcanic Barren Island in the Andaman Sea. Marine Genomics.

Wietz, M., Mansson, M., Gotfredsen, C. H., Larsen, T. O., \& Gram, L. (2010). Antibacterial compounds from marine Vibrionaceae isolated on a global expedition. Marine drugs, 8(12), 2946-2960. 
